\title{
Pyrolusite Bioleaching by an Indigenous Acidithiobacillus sp KL3 Isolated from an Indonesian Sulfurous River Sediment
}

\author{
Endah Retnaningrum ${ }^{1, *}$ and Wahyu Wilopo ${ }^{2}$ \\ ${ }^{1}$ Faculty of Biology, Universitas Gadjah Mada, Jl. Teknika Selatan Sekip Utara, Yogyakarta 55281, Indonesia \\ ${ }^{2}$ Geological Engineering Department, Faculty of Engineering, Universitas Gadjah Mada, \\ Jl. Grafika No. 2, Bulaksumur, Yogyakarta 55281, Indonesia
}

* Corresponding author:

tel: +62-274-580839

email:endahr@ugm.ac.id

Received: September 18, 2018

Accepted: January 5, 2019

DOI: $10.22146 /$ ijc.38898

\begin{abstract}
The manganese bioleaching process of pyrolusite from Kliripan, Indonesia using Acidithiobacillus sp KL3 was investigated. The influence pulp densities of pyrolusite $\left(0.01,0.02,0.03\right.$ and $\left.0.05 \mathrm{~g} / \mathrm{cm}^{3}\right)$ on the bioleaching processes were studied for 16 days. The reduction on $\mathrm{pH}$ values, the increasing of oxidation-reduction potential (ORP), sulfate and manganese concentration were analyzed. The manganese bioleaching mechanism of pyrolusite by the strain was monitored using Scanning Electron Microscope-Energy Dispersive-X-ray Spectroscopy (SEM-EDX). The results indicated that $0.02 \mathrm{~g} / \mathrm{cm}^{3}$ of pyrolusite was considered to be the optimal pulp density for manganese bioleaching process. During this process, $\mathrm{pH}$ values decreased, furthermore resulted in increasing of ORP, the concentration of sulfate and manganese. SEM-EDX analysis clearly showed the evidence of directly bacterial cell attachment into the surface of pyrolusite. Extracellular polymeric substances (EPSs) were further founded on that surface. Sulfur elemental was oxidized by the strain which was then confirmed of resulting in solubilized manganese.
\end{abstract}

Keywords: substrate; oxidation-reduction potential; bacterial cell attachment; sulfur elemental; solubilized manganese

\section{- INTRODUCTION}

Pyrolusite is the most common ore that is widely processed to produce manganese. This manganese is a valuable metal with a wide range of applications in various industries, such as steel, pharmaceuticals, glass, fertilizer and dyes materials [1-2]. In recent years, for extracting that manganese metal from the ore, bioleaching is an innovative biological treatment to be applied in industrial scale. Compared to the traditional mining procedures, it does not need high energy and does not produce toxic pollutants [3-7]. The reserve of manganese metal located at Kliripan, Kulon Progo, Yogyakarta, Indonesia is found in its oxide form as pyrolusite. This deposit was discovered in the form of secondary manganese sediment which was the result of decomposition of volcanogenic manganese sediment a hundred years ago [8-9]. This valuable manganese can be extracted using bioleaching processes which are carried out by groups of iron and sulfur-oxidizing microorganisms.

These microorganisms transform solid compounds, resulting in solubilized metals [10-11]. These microorganisms include genus of Acidithiobacillus, Leptospirillum, Acidianus, Metallosphaera, Sulfurisphaera, Ferromicrobium, and Sulfobacillus. They are chemoautotrophic microorganisms which use $\mathrm{CO}_{2}$ from the atmosphere and obtain energy by oxidation of $\mathrm{Fe}^{2+}$ or reduced sulfur compound [12-14].

According to the previous investigations, the rate of manganese bioleaching depends on the several factors, including manganese ore source characteristics, influence pulp densities of pyrolusite, the composition of the leaching solution, and the activity of the selected strain [14-15]. Previously sulfur-oxidizing bacteria species Acidithiobacillus sp KL3 has been isolated from sulfurous river sediment located at Ungaran, Middle of 
Java, Indonesia. In order to great understanding of the activity of indigenous Acidithiobacillus sp KL3 during bioleaching, various pyrolusite concentrations can be considered. Investigations reported bacterial bioleaching of pyrolusite from Kliripan had not been analyzed. Therefore, it is important to conduct its investigation. The purposes of this research were to investigate the effects of influence pulp densities of pyrolusite on the behavior Acidithiobacillus sp KL3 strain and to analyze the mechanism of physicochemical alterations of pyrolusite during bioleaching. Their alterations were evaluated based on the interaction between the strain and pyrolusite surface following reactions occurred there which resulted in manganese bioleaching.

\section{- EXPERIMENTAL SECTION}

\section{Materials}

The indigenous bacterial chemolithotrophic strain belonging to the species Acidithiobacillus sp KL3 was isolated from sulfuric sediment river at Ungaran, middle of Java, Indonesia. The isolate was grown in $100 \mathrm{~mL}$ of Fe9K medium at $30{ }^{\circ} \mathrm{C}$ and maintained by being transferred to fresh liquid medium every two weeks [16]. The medium of $\mathrm{Fe} 9 \mathrm{~K}$ was prepared by adding $\mathrm{FeSO}_{4} \cdot 7 \mathrm{H}_{2} \mathrm{O}\left(30 \mathrm{~g} \mathrm{~L}^{-1}\right)$ to a $9 \mathrm{~K}$ medium that contained $\left(\mathrm{L}^{-1}\right) 4.25 \mathrm{~g}\left(\mathrm{NH}_{4}\right)_{2} \mathrm{SO}_{4}, 0.14 \mathrm{~g} \mathrm{KCl}, 0.07 \mathrm{~g} \mathrm{~K}_{2} \mathrm{HPO}_{4}, 0.7 \mathrm{~g}$ $\mathrm{MgSO}_{4} \cdot 7 \mathrm{H}_{2} \mathrm{O}$, and $0.02 \mathrm{~g} \mathrm{Ca}\left(\mathrm{NO}_{3}\right)_{2} \cdot 4 \mathrm{H}_{2} \mathrm{O}$. The $\mathrm{pH}$ of its medium was adjusted to $\mathrm{pH} 6.0$ with $10 \mathrm{~N} \mathrm{H}_{2} \mathrm{SO}_{4}$ solution. After the culture has reached its logarithmic phase growth, its culture further used for bioleaching experiment.

Pyrolusite as ore sample was obtained from Kliripan, Kulon Progo, Yogyakarta, Indonesia containing $25 \% \mathrm{Mn}, 30.4 \% \mathrm{Fe}$ and $34.0 \% \mathrm{~S}$. The samples were ground to $0.16-0.125 \mathrm{~mm}$ grain size. These samples were then used as a substrate for the bioleaching investigation.

\section{Instrumentation}

Spectrophotometer Shimadzu UV-1601 was used for analyzing of sulfate concentration. Absorption Spectrophotometer (AAS ContAA 300 Jena) was used for measuring of dissolved manganese concentration. Scanning Electron Microscope-Energy Dispersive X-ray
Spectroscopy (SEM-EDX) (JEOL JSM-T300) was used for investigating the changes in both morphological and elemental characters of pyrolusite surface during manganese bioleaching experiments. Other equipment such as analytical balance, the micropipettes, oven, hot plate with a stirrer, $\mathrm{pH}$ meter, and ORP meter were used for all measurements.

\section{Procedure}

\section{Adaptation tests for toxicity assessment}

Previously, the bacterial strain was acclimatized to pyrolusite in an adaptation period to increase the tolerance of the cells culture to manganese toxicity in the pyrolusite. To determine the maximum tolerance of the bacteria, the variation pulp densities of pyrolusite (0.01, $0.02,0.03,0.05,0.06$ and $\left.0.07 \mathrm{~g} / \mathrm{cm}^{3}\right)$ were added in the culture, then agitated at $120 \mathrm{rpm}$ and incubated at $30{ }^{\circ} \mathrm{C}$ for an adaptation period. During that period, the bacterial growth was observed and determined its maximum tolerance to pyrolusite pulp densities. These pulp densities of pyrolusite treatment which bacterial growth has been successively adapted then were selected for further bioleaching experiment.

\section{Bioleaching experiment}

Three sets of leaching test were performed in $250 \mathrm{~mL}$ Erlenmeyer flasks containing $100 \mathrm{~mL} 9 \mathrm{~K}$ medium. Pyrolusite was then added to each of those flasks at pulp densities of $0.03,0.02,0.03$ and $0.05 \mathrm{~g} / \mathrm{cm}^{3}$. A bacterial culture that reaches logarithmic phase growth was inoculated into the leaching flask. The initial bacterial cell density inoculated was approximately $10^{6}$ CFU which reached its logarithmic phase growth [17]. The culture was then agitated at $120 \mathrm{rpm}$ and incubated at $30{ }^{\circ} \mathrm{C}$ for 16 days. During the regular time of intervals incubation $(0,2,4,6,8,10,12,14$ and 16 days), $2 \mathrm{~mL}$ of sample from the flask experiment was filtered and monitored for dissolved manganese concentration. Oxidation-reduction potential, $\mathrm{pH}$ and sulfate concentration of the sample was also analyzed. Sulfate concentration was measured based on the turbidimetric assay using spectrophotometer at a wavelength of $420 \mathrm{~nm}$ [18]. Dissolved manganese was analyzed using an atomic absorption spectrophotometer, by flame atomic 
absorption spectrometry (FASS) in air/acetylene flame. The device working parameters (air, acetylene, optics, and electronics) were adjusted for maximum absorption for each element. Under the optimum established parameters, standard calibration curves for metals were constructed by plotting absorbency against dissolved manganese concentration [19].

\section{Morphological and elemental analysis of pyrolusite surface during manganese bioleaching}

The changes in both morphological and elemental characters of pyrolusite surface at the time intervals of bioleaching investigations ( 0,9 , and 16 days) were observed under SEM-EDX. Previously, pyrolusite samples were prepared by washing three times with deionized water, then fixed using $2.5 \% \quad(\mathrm{v} / \mathrm{v})$ glutaraldehyde for $24 \mathrm{~h}$ at $4{ }^{\circ} \mathrm{C}$. Finally, samples were dehydrated over an ethanol gradient and coated with gold under vacuum condition [20]. The surface morphology of those prepared samples was investigated by an SEM. The surfaces elemental analyses of $\mathrm{Mn}$ interacted in the samples were carried out by Energy dispersive X-ray elemental X-ray microanalysis (EDS).

\section{Statistical analysis}

All the experiments were performed in triplicate determinations. The results of those experiments were presented as the means \pm standard deviations. Therefore, differences among the values were statistically determined by the analysis of variance (ANOVA) at a significance ( $p$ $<0.05)$. The significant differences among samples were analyzed by the Duncan Multiple Range Test (DMRT).

\section{- RESULTS AND DISCUSSION}

\section{Adaptation of the Bacterial Culture at Variation Pyrolusite Pulp Densities}

Results adaptation test of the bacterial strain in the medium 9K added variation pyrolusite pulp densities was displayed in Fig. 1. In this investigation, the bacteria had reached the lag phase of growth was approximately $10^{2}$ CFU. This number of cells indicated that bacteria had been successively adapted in the medium added pyrolusite pulp densities. The times were required for adaptation of bacteria culture added pyrolusite pulp

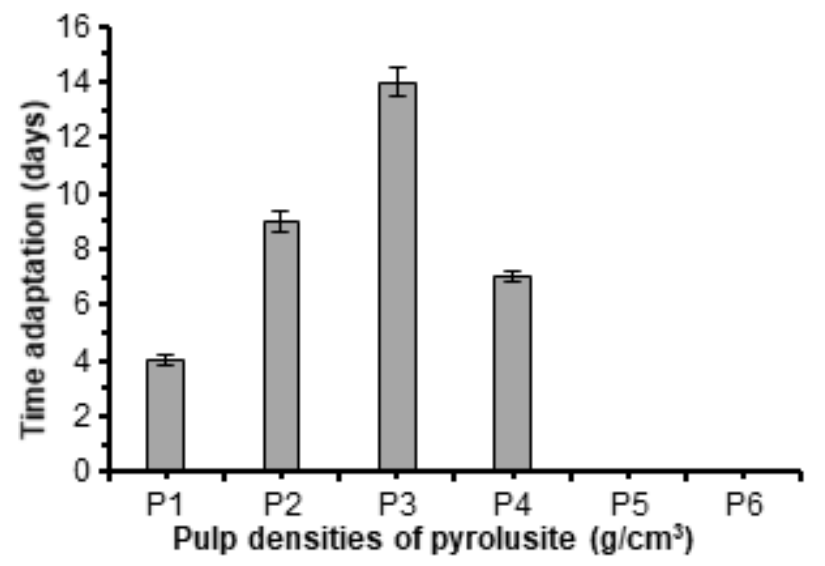

Fig 1. Adaptation period of bacterial strain to pyrolusite pulp densities added in medium $\left(\mathrm{g} / \mathrm{cm}^{3}\right)$. P: Pulp densities of pyrolusite (P), P1: 0.01, P2: 0.02, P3: 0.03, P4: 0.05, P5: 0.06 0, P6: $0.07 \mathrm{~g} / \mathrm{cm}^{3}$

densities of $0.01,0.02,0.03$ and $0.05 \mathrm{~g} / \mathrm{cm}^{3}$ were $4,9,14$ and 7 days, respectively. These increases in the times required to adaptation were due to the manganese toxicity increased at higher pyrolusite pulp density. It showed that the strain could tolerate a high range of pyrolusite pulp densities. However, the strain could not tolerate and grow at pyrolusite pulp densities of 0.06 and $0.07 \mathrm{~g} / \mathrm{cm}^{3}$ even though the time was extended to 20 days incubation. The pyrolusite pulp densities of $0.01,0.02,0.03$ and $0.05 \mathrm{~g} / \mathrm{cm}^{3}$ then were used for the further experiment.

\section{Effect of Pyrolusite Content on pH, ORP and Sulfate Concentration in Bioleaching Experiment}

Results of the observations on the effect of the pyrolusite content on $\mathrm{pH}, \mathrm{ORP}$ and sulfate concentration in bioleaching experiment using indigenous Acidithiobacillus sp KL3 were shown in Fig. 2. During this process, the strain oxidized and remove elemental sulfur of manganese ore to $\mathrm{H}_{2} \mathrm{~S}$, generating in the decreasing of $\mathrm{pH}$ value and manganese solubilization. From this figure, there were decreasing in $\mathrm{pH}$ of all treatments from 5.5-2.4, then achieving the final stable $\mathrm{pH}$ value in the range of 1.3-2.4. The more rapid reduction in $\mathrm{pH}$ was investigated in the treatment of pyrolusite pulp densities 0.02 , followed by $0.01,0.03$ and $0.05 \mathrm{~g} / \mathrm{cm}^{3}$, respectively. In this experiment, its bacterial activities were indicated by an increase in oxidationreduction potential (ORP) values. 

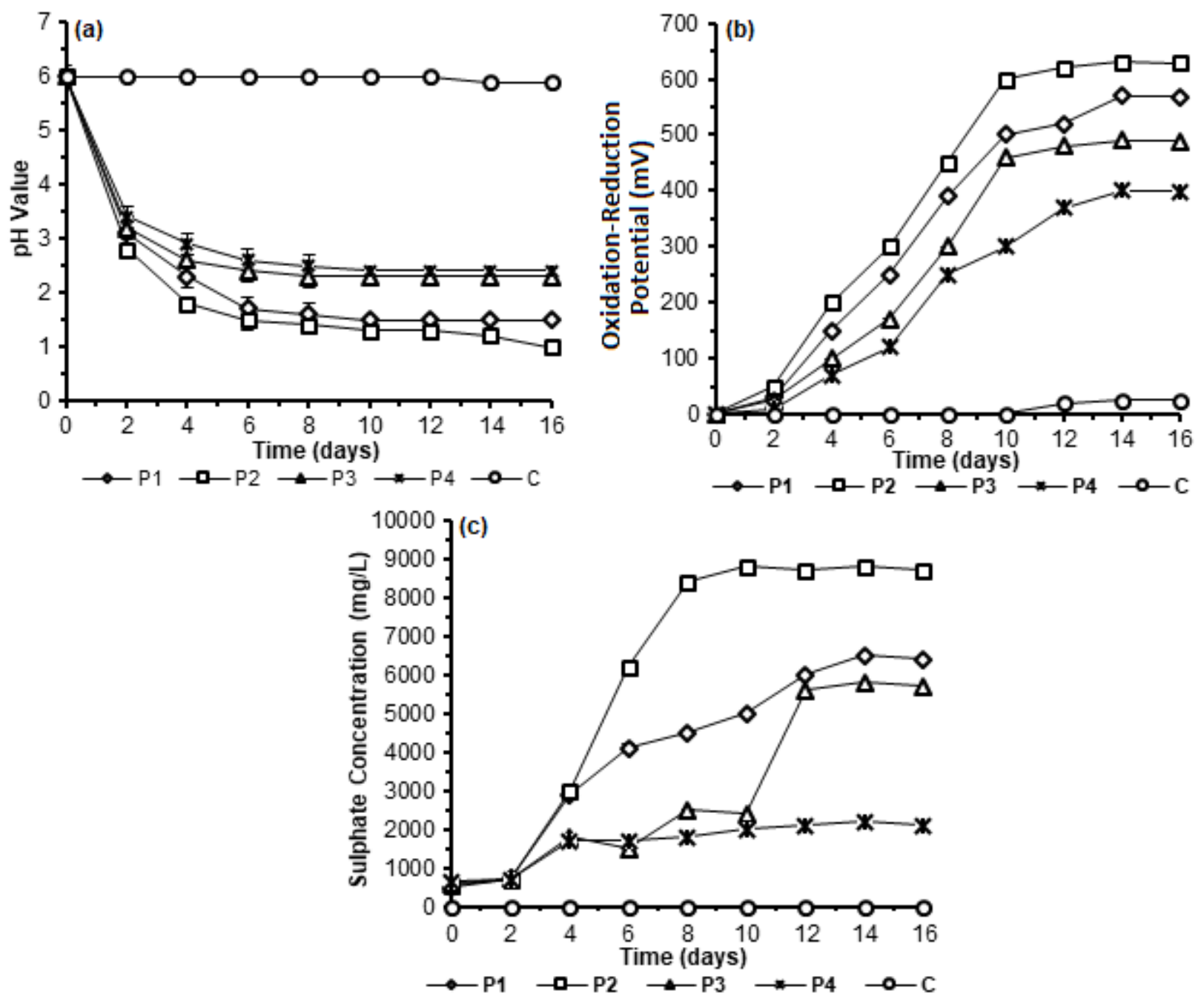

Fig 2. The effect pulp densities of pyrolusite in medium $\left(\mathrm{g} / \mathrm{cm}^{3}\right)$ on the: $(\mathrm{a}) \mathrm{pH}$, (b) oxidation-reduction potential and (c) sulphate concentration during bioleaching (temp: $30^{\circ} \mathrm{C}, \mathrm{pH}: 2.0$, mineral grain size: $0.16-0.125 \mathrm{~mm}$ ). P: Pulp densities of pyrolusite (P), P1: 0.01, P2: 0.02, P3: 0.03, P4: 0.05, C: $0 \mathrm{~g} / \mathrm{cm}^{3}$

The faster increase in ORP value was measured in the treatment of pyrolusite pulp densities 0.02 , followed by $0.01,0.03$ and $0.05 \mathrm{~g} / \mathrm{cm}^{3}$, respectively. The increasing of ORPs values had a positive correlation with the increasing of sulfate accumulated. Therefore, the higher the ORP value induced the increasing sulfate accumulation. In comparison with other treatments, 0.02 $\mathrm{g} / \mathrm{cm}^{3}$ pyrolusite resulted in the highest sulfate production. There were monitored that $\mathrm{H}_{2} \mathrm{SO}_{4}$ as a final metabolic product released by the strain into the culture media gradually increased considerably during its contact time with manganese ore for all treatments. Those $\mathrm{H}_{2} \mathrm{SO}_{4}$ accumulated in the culture showed highest measured at the treatment of pyrolusite 0.02 , followed by pyrolusite $0.01,0.03$ and $0.05 \mathrm{~g} / \mathrm{cm}^{3}$. This measurement indicated that pyrolusite content at a higher concentration than $0.03 \mathrm{~g} / \mathrm{cm}^{3}$ caused negative effects for bacterial leaching activity.

\section{Effect of Pyrolusite Content on Manganese Bioleaching Experiment}

The experimental results on the effect of the pulp densities in the manganese bioleaching were displayed in Fig. 3. As follows from the results, the manganese leaching from pyrolusite tested increases with increasing its pulp densities $\left(0.02 \mathrm{~g} / \mathrm{cm}^{3}\right.$ of pyrolusite induced higher 


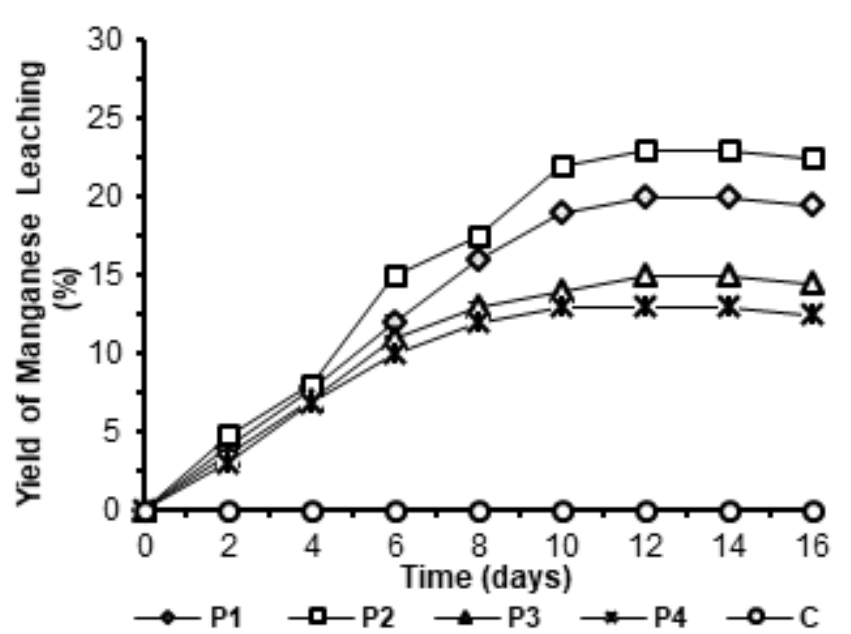

Fig 3. The effect pulp densities of pyrolusite in medium $\left(\mathrm{g} / \mathrm{cm}^{3}\right)$ on the manganese bioleaching. P: Pulp densities of pyrolusite (P), P1: 0.01, P2: 0.02, P3: 0.03, P4: 0.05, C: $0 \mathrm{~g} / \mathrm{cm}^{3}$

manganese leaching than $\left.0.01 \mathrm{~g} / \mathrm{cm}^{3}\right)$. However, pyrolusite pulp densities higher than $0.02 \mathrm{~g} / \mathrm{cm}^{3}(0.03$ and $0.05 \mathrm{~g} / \mathrm{cm}^{3}$ ) caused lower manganese leaching. These results similar to the previous result reported that pyrolusite pulp density more than $0.07 \mathrm{~g} / \mathrm{cm}^{3}$ reduced metal solubilization [21]. Another researcher, Foulkes et al. [22] investigated that pyrolusite pulp density more than $0.06 \mathrm{~g} / \mathrm{cm}^{3}$ declined significantly of $\mathrm{Cu}$ and $\mathrm{Pb}$ solubilization. These phenomena indicated that pyrolusite pulp density impacted on sulfur content. As reported by Chen and Lin [23], higher sulfur concentration given in the leaching experiment could inhibit the growth and activity of strain, thus impacted on the decreasing manganese solubilization. It was measured that the highest efficiently of manganese solubilization was obtained at $0.02 \mathrm{~g} / \mathrm{cm}^{3}$ pyrolusite.

From Fig. 3, it can be seen that the leaching of manganese rose at an enhanced time. The percentage of manganese leaching increased sharply on all treatments and reached a peak at 10 days investigation. After 10 days of leaching, they have not detected manganese leaching. This results indicated that bacterial growth had already reach stationary phase and continue for the death phase. Therefore the manganese leaching processes were stopped.

\section{Morphological and Chemical Characteristics of Pyrolusite Surface during Manganese Bioleaching}

The differences pyrolusite surface during bioleaching experiment have been observed using SEM analysis. The images obtained revealed the evidence about the attack and interactions between the strain and pyrolusite (Fig. 4). Its figure exhibited that pyrolusite was degraded during the observed time intervals $(0,9$, and 16 days). Initially, pyrolusite samples did not show any defects on their surface which was quite uniform, with few cracks and pits. After 9 days of leaching process, several pits appeared on the surface. These pits became larger with increasing leaching time (16 days) then followed by attached and growing the bacterial cells, producing exopolysaccharide covering on the mineral surface. Rod-shaped bacteria was observed clearly in this experiment.
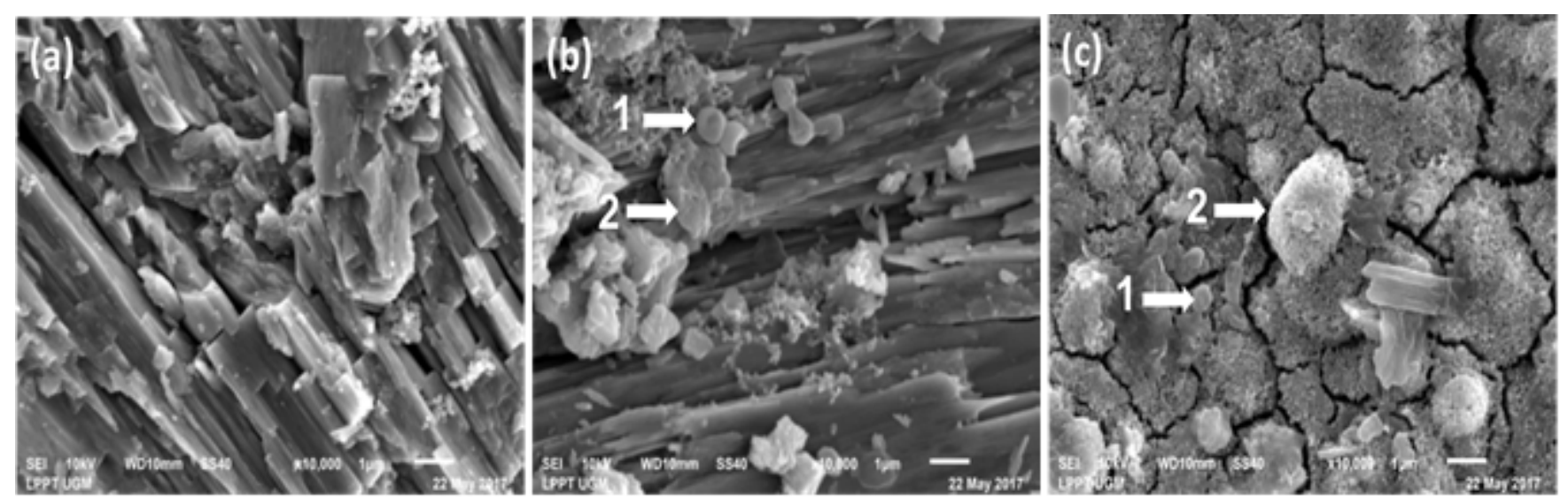

Fig 4. SEM views of pyrolusite grain surface at 0 day (a), 9 days (b), 16 days bioleaching (c), 1: rod shaped bacterium cell; 2: exopolysaccharide (EPS). Photographs were taken at 10,000× amplification 
The exopolysaccharide excreted by bacteria during the leaching experiment induced the formation of precipitates of $\mathrm{Fe}^{3+}$ which observed at 16 days investigation. This investigation was similar to the previous investigation reported that the high amount of EPS complexed $\mathrm{Fe}^{3+}$ production by Thiobacillus delicatus during the bioleaching experiment [24]. The SEM analysis results confirmed the assumption that the strain bacteria play a role in the direct mechanism of bioleaching by producing exopolysaccharide on the surface of pyrolusite. This observation was in accordance with the bioleaching mechanism of arsenopyrite and pyrite [25-27]. A similar result has also reported evidence of the direct mechanism of both pyrite and low-grade pyrolusite during bioleaching investigation [28]. All those investigations explained the direct mechanism of bacterial bioleaching by starting attachment of bacteria cells on the mineral ore surfaces. These attachments generated the physical contact between cells and mineral ore surfaces. Therefore, they produced exopolymeric substances and reacted with $\mathrm{Fe}^{3+}$ compounds in the mineral ores, finally induced Fe-rich secondary precipitates in the samples [29-30].

The transformation of element compositions in the mineral ore during the bioleaching experiment which determined by EDS-X ray microanalysis was shown in Table 1. This result revealed the evidence of the indirect mechanism of manganese solubilization process which was leached from the surface of mineral ore. The $\mathrm{Mn} / \mathrm{S}$ ratio of non-leached pyrolusite sample was higher than of the leached one. Moreover, this ratio has gradually decreased to 0.23 and 0.12 which investigated on 9 and 16 days of leaching process. These results described the mechanism of pyrolusite bioleaching that was started by destructing of that ore, then followed by solubilizing of $\mathrm{Mn}$, further induced the changes of sulfur compounds into the precipitated form. This investigation was positively correlated with the reducing of the sulfur element at 9 days of leaching incubation, then drop at 16 days. In addition, during that 16 days leaching incubation, there were observed the alteration of both $\mathrm{O}$ and $\mathrm{C}$ atomic percentage between the leached samples and the nonleached samples. The raising sharply of $\mathrm{O}$ atomic percentage exhibited the oxidation process of surface
Table 1. Quantitative percentage atomic data of elemental X-ray microanalysis of pyrolusite samples at interval times of 0,9 and 16 days during the bioleaching process

\begin{tabular}{lrrr}
\hline \multirow{2}{*}{ Element } & \multicolumn{3}{c}{ Mass (\%) of pyrolusite samples } \\
\cline { 2 - 4 } & \multicolumn{1}{c}{0 day } & \multicolumn{1}{c}{9 days } & 16 days \\
\hline $\mathrm{C}$ & $0 \pm 0.00$ & $24.8 \pm 0.10$ & $32.8 \pm 0.20$ \\
$\mathrm{O}$ & $5.3 \pm 0.01$ & $11.6 \pm 0.02$ & $46.3 \pm 0.10$ \\
$\mathrm{~S}$ & $34.0 \pm 0.10$ & $48.8 \pm 0.15$ & $16.6 \pm 0.01$ \\
$\mathrm{Mn}$ & $25.0 \pm 0.12$ & $11.3 \pm 0.02$ & $2.03 \pm 0.01$ \\
$\mathrm{Fe}$ & $30.6 \pm 0.20$ & $7.6 \pm 0.01$ & $95.3 \pm 0.10$ \\
Ratio Mn/S & $0.74 \pm 0.00$ & $0.23 \pm 0.00$ & $0.12 \pm 0.00$ \\
\hline
\end{tabular}

Value $\pm \mathrm{SD}, \mathrm{n}=3$

mineral ore during bioleaching experiment. In addition, the percentage of $\mathrm{C}$ atomic also increased during that experiment which indicated the probability of exopolysaccharide polymers production by the strain as previously seen in SEM analysis. Therefore, this study demonstrated that a combination direct and indirect mechanism was probably responsible for manganese bioleaching by Acidithiobacillus sp KL3.

\section{- CONCLUSION}

Pyrolusite of $0.02 \mathrm{~g} / \mathrm{cm}^{3}$ was the best pulp density for bioleaching process of Acidithiobacillus sp KL3 for manganese bioleaching. During this process, $\mathrm{pH}$ values decreased, furthermore resulted in increasing of ORP, the concentration of sulfate and manganese. SEM-EDX clearly showed the bioleaching mechanisms which was started by bacterial attachment into the surface of pyrolusite, then induced the cell to produce exopolysaccharide polymers. Indirect mechanism of bioleaching further resulted in the manganese dissolution. Sulfur elemental in the pyrolusite was oxidized by the strain which was then confirmed of resulting in solubilized manganese.

\section{- ACKNOWLEDGMENTS}

This research was supported by KEMENRISTEK DIKTI Indonesia with the Research Implementation Letter No: 2493/UN1.P.III/DIT-LIT/LT/2017. We are also thankful to Serafica Btari Christiyani Kusumaningrum for providing of Bacterial Strain. 


\section{- REFERENCES}

[1] Hagelstein, K., 2009, Globally sustainable manganese metal production and use, J. Environ. Manage., 90 (12), 3736-3740.

[2] Das, A.P., Ghosh, S., Mohanty, S., and Sukla, L.B., 2014, Consequences of manganese compounds: A review, Toxicol. Environ. Chem., 96 (7), 981-997.

[3] Bayard, R., Chatain, V., Gachet, C., Troadec, A., and Gourdon, R., 2006, Mobilisation of arsenic from a mining soil in batch slurry experiments under biooxidative conditions, Water Res., 40 (6), 1240-1248.

[4] Nguyen V.K., and Lee, J.U., 2015, A comparison of microbial leaching and chemical leaching of arsenic and heavy metals from mine tailings, Biotechnol. Bioprocess Eng., 20 (1), 91-99.

[5] Ghosh, S., Mohanty, S., Akcil, A., Sukla, L.B., and Das, A.P., 2016, A greener approach for resource recycling: Manganese bioleaching, Chemosphere, 154, 628-639.

[6] Pathak, A., Morrison, L., and Healy, M.G., 2017, Catalytic potential of selected metal ions for bioleaching, and potential techno-economic and environmental issues: A critical review, Bioresour. Technol., 229, 211-221.

[7] Ramdhani, E.P., Wahyuni, T., Ni'mah, Y.L., Suprapto, and Prasetyoko, D., 2018, Extraction of alumina from red mud for synthesis of mesoporous alumina by adding CTABr as mesoporous directing agent, Indones. J. Chem., 18 (2), 337-343.

[8] Bhushan, B., Nayak, A., and Kamaluddin, 2017, Role of manganese oxides in peptide synthesis: implication in chemical evolution, Int. J. Astrobiol., 16 (4), 360-367.

[9] Schaefer, M.V., Handler, R.M., and Scherer, M.M., $2017, \mathrm{Fe}(\mathrm{II})$ reduction of pyrolusite $\left(\beta-\mathrm{MnO}_{2}\right)$ and secondary mineral evolution, Geochem. Trans., 18 (1), 7.

[10] Pokorna, D., and Zabranska, J., 2015, Sulfuroxidizing bacteria in environmental technology, Biotechnol. Adv., 33 (6), 1246-1259.

[11] Jeremic, S., Beškoski, V.P., Djokic, L., Branka, V., Vrvić, M.M., Avdalović, J., Cvijović, G.G., Beškoski, L.S., and Nikodinovic-Runic, J., 2016, Interactions of the metal tolerant heterotrophic microorganisms and iron oxidizing autotrophic bacteria from sulphidic mine environment during bioleaching experiments, J. Environ. Manage., 172, 151-161.

[12] Cho, K.H., Kim, B.J., Choi, N.C., Kim, S.B., and Park, C.Y., 2012, Bioleaching of chalcopyrite using indigenous acidophilic bacteria under moderate thermopile conditions, Geosyst. Eng., 15 (4), 229238.

[13] Shiers, D.W., Ralph, D.E., Bryan, C.G., and Watling, H.R., 2013, Substrate utilisation by Acidianus brierleyi, Metallosphaera hakonensis and Sulfolobus metallicus in mixed ferrous ion and tetrathionate growth media, Miner. Eng., 48, 86-93.

[14] Liu, H.C., Nie, Z.Y., Xia, J.L., Zhu, H.R., Yang, Y., Zhao, C.H., Zheng, L., and Zhao, Y.D., 2015, Investigation of copper, iron and sulfur speciation during bioleaching of chalcopyrite by moderate thermophile Sulfobacillus thermosulfidooxidans, Int. J. Miner. Process., 137, 1-8.

[15] Kim, I.S., Lee, J.U., and Jang, A., 2005, Bioleaching of heavy metals from dewatered sludge by Acidithiobacillus ferrooxidans, J. Chem. Technol. Biotechnol., 80 (12), 1339-1348.

[16] Sarcheshmehpour, Z., Lakzian, A., Fotovat, A., Berenji, A.R., Haghnia, G.H., and Seyed Bagheri, S.A., 2009, Possibility of using chemical fertilizers instead of $9 \mathrm{~K}$ medium in bioleaching process of low-grade sulfide copper ores, Hydrometallurgy, 96, 264-267.

[17] Gerayeli, F., Ghojavand, F., Mousavi, S.M., Yaghmaei, S., and Amiri, F., 2013, Screening and optimization of effective parameters in biological extraction of heavy metals from refinery spent catalysts using a thermophilic bacterium, Sep. Purif. Technol., 118, 151-161.

[18] Kolmert, Å., Wikström, P., and Hallberg, K.B., 2000, A fast and simple turbidimetric method for the determination of sulfate in sulfate-reducing bacterial cultures, J. Microbiol. Methods, 41 (3), 179-184.

[19] Khayatian, G., Moradi, M., and Hassanpoor, S., 2018, $\mathrm{MnO}_{2} / 3 \mathrm{MgO}$ Nanocomposite for 
preconcentration and determination of trace copper and lead in food and water by flame atomic absorption spectrometry, J. Anal. Chem., 73 (5), 470478.

[20] Cardell, C., and Guerra, I., 2015, An overview of emerging hyphenated SEM-EDX and Raman spectroscopy systems: Applications in life, environmental and materials sciences, TrAC, Trends Anal. Chem., 77, 156-166.

[21] Lombardi, A.T., Garcia, O., and Mozeto, A.A., 2001, Bioleaching of metals from anaerobic sewage sludge: Effects of total solids, leaching microorganisms, and energy source, J. Environ. Sci. Health. Part A Toxic/Hazard. Subst. Environ. Eng., 36 (5), 793-806.

[22] Foulkes, B., Khanal, S.K., and Sung, S., 2006, Bioleaching of zinc and copper from anaerobically digested swine manure: effect of sulfur levels and solids contents, Water Environ. Res., 78, 202-208.

[23] Chen S.Y., and Lin, J.G., 2001, Effect of substrate concentration on bioleaching of metal-contaminated sediment, J. Hazard. Mater, 82 (1), 77-89.

[24] Rojas-Chapana J.A., and Tributsch, H., 2004, Interfacial activity and leaching patterns of Leptospirillum ferrooxidans on pyrite, FEMS Microbiol. Ecol., 47 (1), 19-29.

[25] d'Hugues, P., Joulian, C., Spolaore, P., Michel, C., Garrido, F., and Morin, D., 2008, Continuous bioleaching of a pyrite concentrate in stirred reactors:
Population dynamics and exopolysaccharide production vs. bioleaching performance, Hydrometallurgy, 94 (1-4), 34-41.

[26] Bellenberg, S., Díaz, M., Noël, N., Sand, W., Poetsch, A., Guiliani, N., and Vera, M., 2014, Biofilm formation, communication and interactions of leaching bacteria during colonization of pyrite and sulfur surfaces, Res. Microbiol., 165 (9), 773-781.

[27] Talla, E., Hedrich, S., Mangenot, S., Ji, B., Johnson, D.B., Barbe, V., and Bonnefoy, V., 2014, Insights into the pathways of iron- and sulfur-oxidation, and biofilm formation from the chemolithotrophic acidophile Acidithiobacillus ferrivorans CF27, Res. Microbiol., 165 (9), 753-760.

[28] Han, Y., Ma, X., Zhao, W., Chang, Y., Zhang, X., Wang, X., Wang, J., and Huang, Z., 2013, Sulfur oxidizing bacteria dominate the microbial diversity shift during the pyrite and low-grade pyrolusite bioleaching process, J. Biosci. Bioeng., 116 (4), 465471.

[29] Sand, W., Gehrke, T., Jozsa, P.G., and Schippers, A., 2001, Biochemistry of bacterial leaching-direct vs. indirect bioleaching, Hydrometallurgy, 59 (2), 159175.

[30] Fortin, D., and Langley, S., 2005, Formation and occurrence of biogenic iron-rich minerals, Earth Sci. Rev., 72 (1-2), 1-19. 